\title{
РЕАКЦІЯ КАРДІОРЕСПІРАТОРНОЇ СИСТЕМИ ЗА УМОВ ФІЗИЧНИХ НАВАНТАЖЕНЬ РІЗНОГО ХАРАКТЕРУ В ЗАЛЕЖНОСТІ ВІД ФІЗІОЛОГІЧНОЇ РЕАКТИВНОСТІ І СТОМЛЕННЯ
}

\author{
Лисенко Олена ${ }^{1,2 A B C D}$, Федорчук Світлана ${ }^{2 A B C D}$ \\ ${ }^{1}$ Київський університет імені Бориса Грінченка, Київ, Украӥна \\ ${ }^{2}$ Національний університет фізичного виховання і спорту України, Київ, Украӥна
}

Внесок автора: А - дизайн дослідження; В - збір даних; С - статистичний аналіз;

$\mathrm{D}$ - підготовка рукопису.

\begin{abstract}
Анотація
Мета - визначити особливості реакції кардіореспіраторної системи кваліфікованих спортсменів при фізичних навантаженнях різного характеру енергозабезпечення виходячи із закону «силових відношень», які пов'язані з фізіологічною реактивністю організму.

Методи. Дослідження за участю кваліфікованих спортсменів, членів збірної команди України 3 легкої атлетики. Використовувались методи комплексного тестування характеристик фізіологічної реактивності КРС на гіперкапнічні $\left(\mathrm{CO}_{2}-\mathrm{H}^{+}\right)$зрушення дихального гомеостазису у стані спокою та під час виконання тестових фізичних навантажень.

Результати. Виявлена позитивна залежність між чутливістю кардіореспіраторної системи (КРС) на гіперкапнічний стимул та рівнем і швидкістю розгортання функціональних реакцій за умов аеробного навантаження середньої інтенсивності, а також негативний зв'язок в умовах тривалого аеробного навантаження максимальної інтенсивності. Зворотна залежність відзначалася між чутливістю КРС на гіперкапнічний стимул і рівнем економічності та стійкості функціонування, а також позитивний зв'язок з рівнем активності анаеробних процесів в енергозабезпеченні навантажень.

Висновки. Визначені особливості реакції кардіореспіраторної системи кваліфікованих спортсменів при фізичних навантаженнях різного характеру енергозабезпечення.

Ключові слова: реактивність, кардіореспіраторна система, кваліфіковані спортсмени, гіперкапнічні зрушення дихального гомеостазису, фізичні навантаження.

Вступ

У спортивній фізіології в основу вивчення перебігу процесу адаптації організму спортсменів до змінних умов спортивної діяльності покладені закономірності динаміки розвитку втоми і фазовості відновлення після напружених спортивних навантажень, тренувальних занять i їх серій, а також враховується переважна спрямованість фізичних навантажень $[10,11,13]$.

Відомо, що амплітуда фізіологічних відповідей на подразники різного характеру і сили, а також співвідношення “стимул-реакція" залежить від віку, функціонального стану організму та рівня його тренованості $[1,5]$. Ці зміни в силу властивого організму пристосувального реагування (реактивності) є причиною адаптаційних

змін, що відображаються на напруженості процесу збереження гомеостазису при наростаючій дії подразника - фізичного навантаження $[2,4$, $7,11]$. Таким чином, процес адаптації організму спортсменів до напружених фізичних навантажень можливо описати використовуючи поняття «фізіологічної реактивності» і використовуючи зміни фізіологічної реактивності під час виконання фізичних навантажень.

У спорті вищих досягнень, в умовах білямаксимальної реалізації функціональних можливостей систем організму, індивідуальні особливості реактивності організму проявляються не тільки в ступені реакцій на фізичні навантаження, але і в різній швидкості їх зміни під впливом повторюваних фізичних навантажень у
\end{abstract}


процесі тренування $[11,13]$. Причому, характер цих змін і їхньої швидкості, ймовірно, залежать від нерівномірності фізичних навантажень і особливостей спортивного тренування в цілому. $€$ всі підстави вважати, що зміни фізіологічної реактивності при її комплексній характеристиці з урахуванням, як вегетативних реакцій, так i властивостей нейродинамічних функцій, можуть відображати функціональний потенціал і індивідуальний характер реалізації енергетичних можливостей організму в умовах напружених фізичних навантажень і взаємообумовлені характером спортивного тренування $[6,7,12]$.

Під час аналізу експериментальних даних 3 таких позицій виникає необхідність врахування типу фізіологічної реактивності, який обумовлює пристосування організму до ефективного виконання певної вузькоспеціалізованої діяльності, що вимагає максимального прояву різних сторін енергозабезпечення роботи $[5,9,10,13]$. У будь-якому випадку, взаємодія між організмом і подразником середовища залежить від характеру (сили, тривалості) впливу і від індивідуальної здатності організму реагувати на цей подразник [11].

Особливу актуальність у спортивній фізіології набуває розробка критеріїв індивідуальної корекції і спрямованості процесу адаптації кваліфікованих спортсменів до напружених тренувальних навантажень на підставі змін фізіологічної реактивності кардіореспіраторної системи (КРС) та виходячи із закону «силових відношень» (співвідношення «стимул-реакція»).

Дослідження проводилося відповідно до держбюджетної науково-дослідної теми «Технологія оцінки ризику травматизму спортсменів за електронейроміографічними і психофізіологічними показниками» (№ держреєстрації 0119U000307) Міністерства освіти і науки України.

Мета дослідження - визначити особливості реакції кардіореспіраторної системи кваліфікованих спортсменів під час фізичних навантажень різного характеру енергозабезпечення виходячи із закону «силових відношень», які пов'язані 3 фізіологічною реактивністю організму.

\section{Методи}

У передзмагальному періоді підготовки були проведені дослідження за участю кваліфікованих спортсменів (КМС-МС), членів збірної команди України з легкої атлетики (54 спортсмени).

Використовувались методи комплексного тестування характеристик фізіологічної реактивності КРС на гіперкапнічні $\left(\mathrm{CO}_{2}-\mathrm{H}^{+}\right)$зрушення дихального гомеостазису в стані спокою та під час виконання тестових навантажень. Прогресуючу $\mathrm{CO}_{2}-\mathrm{H}^{+}$-стимуляцію створювали методом зворотнього дихання в системі «bag in the box», робоча система якого заповнювалася газовою сумішшю з 50-60\% вмістом $\mathrm{O}_{2}$. У якості тестів використовувалися фізичні навантаження середньої аеробної потужності 3 робочим рівнем $\mathrm{VO}_{2} 52-55 \%$ від $\mathrm{VO}_{2} \max$ і максимальної аеробної потужності - 3 рівнем $\mathrm{VO}_{2} 80-93$ \% від $\mathrm{VO}_{2} \max$, що виконувалися на тредмілі LE-200 CE. Для оцінки реакції КРC на тестові навантаження використовувався ергоспірометричний комплекс "Oxycon Pro" (“Jager", Німеччина) і методичний підхід оцінки фізіологічної реактивності КРС $[1,9]$. Кінетичні характеристики реакції КРС на тестові навантаження визначали з урахуванням швидкості початкової частини реакції, iї піку та стійкості.

Тестування проводилося після дня відпочинку при стандартній системі харчування i питного режиму. Спортсмени були обізнані про зміст тестів і дали згоду на їх проведення.

Статистична обробка результатів проводилася 3 використанням комп'ютерної програми «Microsoft Excel» 3 визначенням основних статистичних показників: середнє арифметичне значення (M), середнє квадратичне відхилення (SD), коефіцієнт варіації (CV,\%), мінімальне і максимальне значення показника у вибірці, медіану та ін.

\section{Результати та обговорення}

Проведені попередні дослідження за умов діï прогресуючої гіперкапнічної стимуляції дозволив виявити три групи спортсменів, які відрізнялися за типом реагування КРС на $\mathrm{CO}_{2}-$ $\mathrm{H}^{+}$-стимул $[5,11]$. Так, у кваліфікованих спортсменів-спринтерів відзначався тип реагування, який відповідав уявленням про гіперкінетичний тип і характеризувався відносно високим рівнем чутливості і загальної реактивності вентиляторної і циркуляторної реакції $\left(\mathrm{rV}_{\mathrm{E}} / \mathrm{rP}_{\mathrm{A}} \mathrm{CO}_{2}\right.$ $2,27 \pm 0,16$ л хв ${ }^{-1}$ мм рт.ст. $\left.{ }^{-1}\right)$ на $\mathrm{CO}_{2}-\mathrm{H}^{+}$-стимул. Спортсменів-стаєрів відрізняв знижений рівень чутливості КРС на $\mathrm{CO}_{2}-\mathrm{H}^{+}$-стимул $\left(\mathrm{rV}_{\mathrm{E}} / \mathrm{rP}_{\mathrm{A}} \mathrm{CO}_{2}\right.$ 
$1,09 \pm 0,14$ л хв ${ }^{-1}$ мм рт.ст. $\left.{ }^{-1}\right)$, що відповідав уявленням про гіпокінетичний тип реагування на гіперкапнічні і гіпоксичні зрушення дихального гомеостазису.

У спортсменів зі зниженим рівнем чутливості КРС на $\mathrm{CO}_{2}-\mathrm{H}^{+}$-стимул (III група) за умов навантажень середньої аеробної потужності відзначався відносно знижений рівень реакції КРС за рівнем легеневої вентиляції $\left(\mathrm{V}_{\mathrm{E}}\right)$, споживання $\mathrm{O}_{2}\left(\mathrm{VO}_{2}\right)$ і частоті серцевих скорочень (HR), що становило 82-94 \% від середніх даних для всіх спортсменів, що були прийняті за $100 \%(\mathrm{p}<0,05)$. За умов фізичних навантажень максимальної аеробної потужності високий рівень фізичної працездатності забезпечувався вірогідно вищою швидкістю споживання $\mathrm{O}_{2}\left(\mathrm{VO}_{2} 122,16 \pm 2,18 \%\right)$ i рівнем легеневої вентиляції $\left(\mathrm{V}_{\mathrm{E}} 117,77 \pm 2,09 \%\right)$. При цьому, при виконанні навантажень різної аеробної потужності у спортсменів зі зниженим рівнем фізіологічної реактивності відмічався вищий рівень ефективності легеневої вентиляції за величиною вентиляційного еквіваленту для $\mathrm{O}_{2}\left(\mathrm{EQO}_{2} 91,02-97,13 \%\right)$, економічності $\left(\mathrm{O}_{2}-\right.$ пульс 121,34-124,96 \%) серцевого циклу.

Величина коефіцієнту функціональної стійкості для «дрейфу» HR i вентиляційного еквіваленту для $\mathrm{O}_{2}$ за умов навантажень середньої (КФС НRст $70,22 \pm 6,03 \%$, КФС EQО 2 ст 72,85 $\pm 5,84 \%$ ) і макси-

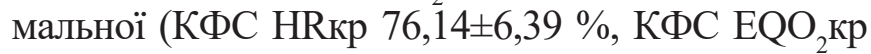

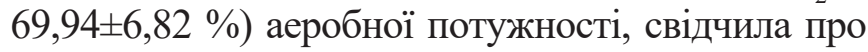
більшу стійкість функціональних реакцій під час тривалих навантажень у осіб зі зниженим рівнем чутливості КРС на $\mathrm{CO}_{2}-\mathrm{H}^{+}$-стимул, що поєднувалося із нижчим рівнем дихальної компенсації метаболічного ацидозу, про що побічно свідчив відносно нижчий рівень виділення $\mathrm{CO}_{2}\left(\mathrm{VCO}_{2} 82,19\right.$ $83,76 \%)$ і газообмінного відношення $\left(\mathrm{VCO}_{2} / \mathrm{VO}_{2}\right.$ $82,02-93,79 \%)$.

В осіб із високим рівнем чутливості КРС на $\mathrm{CO}_{2}-\mathrm{H}^{+}$-стимул, навпаки, за умов фізичних навантажень середньої аеробної потужності відзначався вищий рівень реакції КРС за рівнем легеневої вентиляції, споживання $\mathrm{O}_{2}$ i частоти серцевих скорочень (показники змінювалися в межах 103,49-126,76 \% від середніх даних, що були прийняті за 100 \%). За умов навантаження максимальної аеробної потужності знижений рівень фізичної працездатності поєднувався зі зниженим рівнем реакції КРС $\left(\mathrm{V}_{\mathrm{E}}\right.$ $83,29 \pm 5,09 \%$, VO $79,13 \pm 5,73 \%$ \%). При цьому, незалежно від рівня реакції кардіореспіраторної системи за $\mathrm{V}_{\mathrm{E}}, \mathrm{VO}_{2}$ i HR, виконання тестових навантажень завжди супроводжувалося підвищеним рівнем дихальної компенсації метаболічного ацидозу $\left(\mathrm{VCO}_{2} 116,29-127,41 \%, \mathrm{VCO}_{2} /\right.$ $\mathrm{VO}_{2} 112,96-123,78$ \%) за умов навантажень різної потужності, а також зниженим рівнем економічності і стійкості (КФС HR 123,96-130,38 \%, КФС ЕQО 2 137,47-143,88 \%) функціонування кардіореспіраторної системи.

Таким чином, у спортсменів із відносно зниженим рівнем чутливості КРС на $\mathrm{CO}_{2}-\mathrm{H}^{+}$-стимул зі збільшенням сили подразника (інтенсивності фізичного навантаження) збільшувався рівень фізіологічної реакції кардіореспіраторної системи за умов фізичних навантажень із різним характером енергозабезпечення. У той же час, високий рівень фізіологічної реактивності організму на зрушення дихального гомеостазису в стані спокою поєднувався 3 високим рівнем фізіологічної реакції кардіореспіраторної системи за умов дії подразника слабкої сили (аеробне навантаження малої і середньої аеробної потужності) і знижений рівень реакції на дію подразника сильної сили (навантаження максимальної аеробної потужності).

За умов рівномірного навантаження середньої аеробної потужності $\left(\mathrm{VO}_{2} 52-55 \%\right.$ від $\mathrm{VO}_{2} \max$ ) висока швидкість розгортання функціональних реакцій, яка оцінювалася за напівперіодом реакції збільшення споживання $\mathrm{O}_{2}$ $\left(\mathrm{T}_{50} \mathrm{VO}_{2}, \mathrm{c}\right)$, відзначалася у спортсменів 3 високим рівнем фізіологічної реактивності $\left(\mathrm{T}_{50} \mathrm{VO}_{2 \mathrm{CT}}\right.$ $75,01 \pm 7,16 \%$ ), а найменша швидкість розгортання функціональних реакцій була властива для спортсменів зі зниженим рівнем чутливості КРС на $\mathrm{CO}_{2}-\mathrm{H}^{+}$-стимул $\left(\mathrm{T}_{50} \mathrm{VO}_{2 \mathrm{CT}} 125,91 \pm 9,71 \%\right)$. 3 підвищенням потужності фізичного навантаження (максимальна аеробна потужність навантаження $3 \mathrm{VO}_{2} 86-93$ \% від $\left.\mathrm{VO}_{2} \max \right)$ вища рухливість функціональних реакцій відзначалася в спортсменів зі зниженим рівнем чутливості КРС на $\mathrm{CO}_{2}-\mathrm{H}^{+}$-стимул $\left(\mathrm{T}_{50} \mathrm{VO}_{2 \text { КР }} 80,95 \pm 4,12 \%\right)$.

Тобто, за умов навантаження середньої аеробної потужності високий рівень чутливості КРС на $\mathrm{CO}_{2}-\mathrm{H}^{+}$-стимул, як це мало місце у спортсменів-спринтерів, зумовлював швидку реакцію КРС на зміну кислотно-лужного стану крові, а за умов тривалого навантаження максимальної аеробної потужності знижена чутливість КРС до гіперкапнії у спортсменів-стаєрів сприяли мобілізації, а не пригніченню швидко- 
сті розгортання функціональних реакцій за умов наростаючого ступеня ацидоза, втоми.

Виявлені в осіб з різним рівнем фізіологічної реактивності відмінності реакції КРС при виконанні фізичних навантажень різної потужності проаналізовані виходячи із закону «силових відношень» [3]. У осіб з високим рівнем чутливості КРС на $\mathrm{CO}_{2}-\mathrm{H}^{+}$-стимул при дії подразника середньої сили, як це мало місце за умов фізичного навантаження середньої аеробної потужності, відзначався вищий рівень відповідної реакції, а 3 підвищенням сили подразника (навантаження максимальної аеробної потужності) знижувався рівень відповідної реакції. Подібне співвідношення «стимул-реакція» може мати місце в дітей і підлітків, при цьому зниження відповідей на збільшення сили подразника пояснювали виснаженням функціональних резервів організму [3]. У даному випадку в спортсменів мають місце співвідношення, які пов'язані 3 рівнем фізіологічної реактивності КРС і відображають специфіку пристосування системи для ефективної реалізації її можливостей за умов прояву вузькоспеціалізованої працездатності на коротких змагальних дистанціях та реалізації для цього анаеробного енергетичного потенціалу організму спортсменів.

У спортсменів зі зниженим рівнем фізіологічної реактивності на дію подразника середньої сили відмічався знижений рівень відповідної реакції КРС, а зі збільшенням сили подразника - підвищення рівня відповідної реакції. Зниження чутливості реакцій КРС на $\mathrm{CO}_{2}-\mathrm{H}^{+}$-стимул у цьому випадку відображає збільшення ii функціональних можливостей, і ступінь такого зниження чутливості до $\mathrm{CO}_{2}$ тісно пов'язана зі збільшенням максимального рівня споживання $\mathrm{O}_{2}$ та деякими іншими проявами максимальних можливостей кардіореспіраторної системи i фізичної працездатності за умов навантаження максимальної аеробної потужності. Згідно літературних даних, знижена відповідь на подразнення середньої сили і максимальна реакція на екстремальний стимул властива особам 3 гарною фізичною підготовкою і спортсменам 3 високою спортивною працездатністю [1, 5, 9, 11] за умов фізичних навантажень, що вимагають прояву загальної витривалості.

Таким чином, спортсменів з різним рівнем фізіологічної реактивності кардіореспіраторної системи на зрушення дихального гомеостазису відрізняє різне співвідношення в «стимул-реакція». Відзначався позитивний взаємозв'язок між характеристиками чутливості і загальної реактивності КРС на $\mathrm{CO}_{2}-\mathrm{H}^{+}$-стимул з рівнем реакцій КРС і швидкістю їх розгортання за умов аеробного навантаження середньої потужності $\left(\mathrm{VO}_{2}\right.$ 52-55 \% від $\left.\mathrm{VO}_{2} \max \right)$ і негативний взаємозв'язок 3 рівнем реакції кардіореспіраторної системи за умов фізичних навантажень максимальної аеробної потужності ( $\mathrm{VO}_{2} 86-93 \%$ від $\left.\mathrm{VO}_{2} \max \right)$. Протилежний характер взаємозв'язку відзначався між рівнем чутливості і реактивності кардіореспіраторної системи на зрушення дихального гомеостазису в стані спокою та показниками, що характеризували рівень економічності і стійкості функціональних систем, а також позитивний взаємозв'язок з показниками питомої ваги анаеробних гліколітичних процесів у енергозабезпеченні фізичного навантаження як середньої, так і максимальної аеробної потужності.

Таким чином, у процесі довгострокової адаптації організму до спортивних навантажень має місце характер оптимізації фізіологічної реактивності (чутливості і стійкості) КРС до зрушень дихального гомеостазису. Це може виступати як механізм формування потужності дихальної компенсації метаболічного ацидозу, що забезпечував би ефективність основних факторів, що визначають рівень фізичної працездатності і енергетичних процесів за умов змагальних навантажень 3 різним співвідношення аеробних і анаеробних процесів в їхньому енергозабезпеченні.

Отримані дані підтверджують, що спеціалізований розвиток тих чи інших варіантів енергозабезпечення навантаження накладає відбиток на реактивні властивості КРС і вказують на модифікацію ролі кардіореспіраторної системи при пристосуванні до навантажень різного характеру енергозабезпечення - змінюється співвідношення ï значення у постачанні працюючих м'язів киснем і у їх «очищенні» від метаболітів. Така модифікація полягає і в підвищенні чутливості, і загальної реактивності КРС на $\mathrm{CO}_{2}-\mathrm{H}^{+}$-стимул, і ацидемію при виконанні швидкісно-силових тренувальних навантажень анаеробного характеру, і в зниженні чутливості - під час використання засобів тренувань, спрямованих на розвиток аеробних можливостей і підвищення рівня загальної витривалості спортсменів. 


\section{Висновки}

1. Кваліфікованих спортсменів з різним типом фізіологічної реактивності (за чутливістю і стійкістю реакцій кардіореспіраторної системи на адекватні гуморальні стимули), які спеціалізуються на різних за часом подолання змагальних дистанціях, відрізняе різне співвідношення в «стимул-реакція» за умов фізичних навантажень різного характеру.

2. Високий рівень фізіологічної реактивності організму визначає високий рівень реакції КРС в умовах дії подразника слабкої сили (навантаження малої і середньої аеробної потужності) і знижений рівень реакції на дію подразника великої сили (навантаження максимальної аеробної потужності), що зумовлює більш швидку реакцію кардіореспіраторної системи в початковій частині фізичної аеробного навантаження середньої потужності і знижену - в умовах навантаження максимальної аеробної потужності.

3. У спортсменів зі зниженим рівнем фізіологічної реактивності більш виражена реакція мала місце при значно більшій силі подразника, що поєднувалося зі зниженою швидкістю розгортання функціональних реакцій при навантаженні середньої аеробної потужності. Знижена чутливість реакцій кардіореспіраторної системи до гіперкапнії у спортсменів-стаєрів сприяли мобілізації їх аеробних можливостей більш тривалий час без пригнічення швидкості розгортання функціональних реакцій в умовах тривалого навантаження максимальної аеробної потужності.

4. У процесі довгострокової адаптації організму до спортивних навантажень має місце певний характер оптимізації фізіологічної реактивності (чутливості і стійкості) КРС до зрушень дихального гомеостазису. Це може виступати як механізм формування потужності дихальної компенсації метаболічного ацидозу, що забезпечував би ефективність основних факторів, що визначають рівень фізичної працездатності й енергетичних процесів за умов змагальних навантажень 3 різним співвідношенням аеробних і анаеробних процесів у їх енергозабезпеченні.

\section{References}

1. Berezovsky VA, Serebrovskaya TV. Individual reactivity of the human respiratory system and its assessment. Fiziologicheskiy zhurnal. 1988; 34, 6: 3-7. Березовский ВА, Серебровская ТВ. Индивидуальная реактивность системы дыхания человека и ее оценка. Физиологический журнал. 1988; 34, 6: 3-7.

2. Berezovsky VA, Levashov MI. Growth of reserve potential in humans with exposure to intermittent normobaric hypoxia. Aviakosmicheskaya i ekologicheskaya meditsina. 2000; 34 (2): 39-46.

Березовский ВА, Левашов МИ. Рост резервного потенциала у человека при экспозиции прерывистой нормобарической гипоксией. Авиакосмическая и экологическая медицина. 2000; 34 (2): 39-46.

3. Garkavi LH, Kvakina EB. Diagnosis and correction of the state of the body from the standpoint of periodic patterns of development of adaptive reactions. Problemy neyrokibernetiki: diagnostika i korrektsiya funktsional'nogo sostoyaniya. Rostovon-Don; 1989. 3-12.

Гаркави ЛХ, Квакина ЕБ. Диагностика и коррекция состояния организма с позиций периодической закономерности развития адаптацион- ных реакций. Проблемы нейрокибернетики: диагностика и коррекция функционального состояния. Ростов-на-Дону; 1989. 3-12.

4. Isaev AP, Rybakov VV, Erlikh VV. Strategies for the formation of adaptive reactions in athletes. Fundamentals of the theory of adaptation and the laws of its formation in the sport of high and higher achievements. Vestnik YuzhnoUral'skogo gosudarstvennogo universiteta. Seriya: Obrazovaniye, zdravookhraneniye, fizicheskaya kul'tura. 2012; 21 (280): 46-56.

Исаев АП, Рыбаков ВВ, Эрлих ВВ. Стратегии формирования адаптационных реакций у спортсменов. Основы теории адаптации и закономерности ее формирования в спорте высоких и высших достижений. Вестник Южно-Уральского государственного университета. Серия: Образование, здравоохранение, физическая культура. 2012; 21 (280): 46-56.

5. Harms CA, Stager JM. Low chemoresponsiveness and inadequate hyperventilation contribute to exercise-induced hypoxemia. Journal of Applied Physiology. 1995; 79: 575-580.

6. Lysenko Olena. Cardiorespiratory responseveness and manifestations of energy potential for elite 
athletes. Research Yearbook. Studies in Physical Education and Sport. 2007; 13 (2): 235-238.

7. Lysenko EN. The manifestation of the stability of the reactions of the cardiorespiratory system in qualified athletes in conditions of achieving the maximum level of $\mathrm{O}_{2}$ consumption. Sportivnaya meditsina. 2008; 1: 42-47.

Лысенко ЕН. Проявление устойчивости реакций кардиореспираторной системы у квалифицированных спортсменов в условиях достижения максимального уровня потребления $\mathrm{O}_{2}$. Спортивная медицина. 2008; 1: 42-47.

8. Lysenko OM. Optimization of the physiological reactivity of the respiratory system in the process of adaptation to intense muscular activity [actoreferat]. Київ, 2013. 43 р.

Лисенко ОМ. Оптимізація фізіологічної реактивності системи дихання в процесі адаптації до напруженої м'язової діяльності [автореферат]. Київ, 2013. 43 с.

9. Mishchenko VS, Lysenko EN, Siversky DE. Changes in the sensitivity of the human respiratory system to hypercapnic and hypoxic stimuli when exposed to physical exertion of varying intensity. Fiziologicheskiy zhurnal im. I.M.Sechenova. 1994; 7: 23-28.

Мищенко ВС, Лысенко ЕН, Сиверский ДЕ. Изменение чувствительности системы дыхания человека на гиперкапнический и гипоксический раздражители при воздействии физических нагрузок различной интенсивности. Физиологический журнал им. И.М.Сеченова. 1994; 7: 23-28.

10. Mishchenko VS, Pavlik AI, Savchin S, Dyachenko AY, Lysenko EN, Fedotov AS, Vinogradov BE, etc. Functional preparedness of qualified athletes: approaches to improve the specialization of assessment and directional improvement. Nauka $\mathrm{v}$ Olimpiyskom sporte. 1999; 61-69.

Мищенко ВС, Павлик АИ, Савчин С, Дьяченко АЮ, Лысенко ЕН, Федотов АС, Виноградов ВЕ и др. Функциональная подготовленность квалифицированных спортсменов: подходы к повышению специализированности оценки и направленному совершенствованию. Наука в Олимпийском спорте. Спец. выпуск. 1999; 61-69.

11. Mishchenko VS, Lysenko OM, Vinogradov VE. Types of physiological reactivity of the respiratory system and the specificity of the manifestation of the special ability of athletes. Fiziolohichnyy zhurnal. 2006; 52 (4): 69-77.

Міщенко ВС, Лисенко ОМ, Виноградов ВС. Типи фізіологічної реактивності системи дихання і специфіка прояву спеціальної працездатності спортсменів. Фізіологічний журнал. 2006; 52 (4): 69-77.

12. Steele J, Fisher J, McGuff D. Resistance Training to Momentary Muscular Failure Improves Cardiovascular Fitness in Humans: A Review of Acute Physiological Responses and Chronic Physiological Adaptations. Journal of Exercise Physiology online. 2012; 5 (3): 53-80.

13. Vella CA, Robergs RA, Yamada PM. Fitness, body size, ventilation and the oxygen cost of breathing in adults. Journal of Exercise Physiology online. 2008; 11 (6): 67-76.

14. Zasada M, Mishchenko W, Sawczyn S, Lysenko O, Vinogradov W, Tomiak T. Cardiorespiratory responsiveness throughout continuous strenuous physical exercise and its individualities in endurance athletes. Medical and Biological Sciences. 2011. 25 (4): 55-64.

\section{Інформація про авторів:}

\section{Лисенко Олена}

https://orcid.org/0000-0002-1239-2596

Київський Університет імені Бориса Грінченка, Київ, Україна

o.lysenko@kubg.edu.ua

\section{Федорчук Світлана}

Національний університет фізичного виховання і спорту України, Київ, Україна

Отримано: 04.06.2019;

Прийнято 17.06.2019; Опубліковано: 28.06.2019. 